\title{
Greenhouse gas emission from wastewater irrigated soils
}

\author{
R. Thangarajan ${ }^{1,2}$, A. Kunhikrishnan ${ }^{3}$, B. Seshadri, ${ }^{1,2}$, \\ N. S. Bolan ${ }^{1,2} \&$ R. Naidu ${ }^{1,2}$ \\ ${ }^{1}$ Centre for Environmental Risk Assessment and Remediation (CERAR), \\ University of South Australia, Australia \\ ${ }^{2}$ Cooperative Research Centre for Contaminants Assessment and \\ Remediation of the Environment (CRC CARE), \\ University of South Australia, Australia \\ ${ }^{3}$ Chemical Safety Division, Department of Agro-Food Safety, \\ National Academy of Agricultural Science, Republic of Korea
}

\begin{abstract}
With increasing demand for world water supply, wastewater reuse is a great opportunity to meet the water need, especially for agricultural and industrial development. Wastewater originates from many sources and hence its composition differs from origin and treatment processes. Wastewater rich in organic matter acts as a soil conditioner, thereby enhancing soil health. Wastewater also acts as a source of nutrient input in agriculture which in turn can reduce, or even eliminate the need for commercial fertilisers. However, wastewater usage in agriculture poses several threats like eutrophication, salinity, toxic chemicals (heavy metal(loids), pesticides), pathogen contamination, and most notably, nutrient leaching, and greenhouse gas (GHG) emission. These threats affect public health, soil and ground water resources, environment, crop quality, ecological, and property values. Biological degradation of the organic matter present in wastewater is considered one of the anthropogenic sources of major GHGs (carbon dioxide $\left(\mathrm{CO}_{2}\right)$, nitrous oxide $\left(\mathrm{N}_{2} \mathrm{O}\right)$, and methane $\left(\mathrm{CH}_{4}\right)$. In this paper, an overview of various sources of wastewater, effects of wastewater application on GHG emission from soil, and the strategies to mitigate wastewater-induced GHG emission from soils is presented.

Keywords: agriculture, greenhouse gas, irrigation, mitigation, wastewater.
\end{abstract}




\section{Introduction}

Wastewaters originate from a number of sources including domestic sewage, agricultural, urban and industrial effluents, and stormwater. Wastewater irrigation has many beneficial effects, including groundwater recharging and nutrient supply to plants. However, wastewater application to soil is known to increase emissions of greenhouse gas (GHG). Agricultural activities are an important source of anthropogenic GHG, contributing up to $20 \%$ of the annual emissions [1]. Carbon dioxide is the most abundant GHG in the atmosphere (360 ppmv), and is readily generated by anthropogenic activities, essentially by the burning of fossil fuels and wood. Though the atmospheric concentration of $\mathrm{CH}_{4}$ is relatively low (1.72 ppmv), its global warming potential (GWP) is 21 times greater than that of $\mathrm{CO}_{2}$ [1]. Methane is produced mainly from rice cultivation, anaerobic management of solid waste, biomass burning, and ruminant digestive processes. Nitrous oxide is generated by microbial activity in wastewater, soils and oceans during the degradation of nitrogen $(\mathrm{N})$ rich $\mathrm{OM}$, with a GWP of 310 times that of $\mathrm{CO}_{2}[1,2]$. Mackenzie and Mackenzie [2] documented an increasing amount of $\mathrm{N}_{2} \mathrm{O}$ emissions due to microbial transformation of the $\mathrm{N}$ contained in wastewater.

The GHG emission takes place during wastewater treatment, storage, and also when applied to the land. For example, livestock derived $\mathrm{CH}_{4}$ represents $6-10 \%$ of total annual $\mathrm{CH}_{4}$ emissions in the US of which significant proportion is derived from livestock wastes including manures and effluents. Wastewater is often applied to soil as it is rich in nutrients and OM. Application of organic residues to soil increases crop growth and improves soil structure. The OM in the wastewater sludge is mineralised, so the emission of $\mathrm{CO}_{2}$ and $\mathrm{N}_{2} \mathrm{O}$ increases from a organic waste-amended soil. The ammonium added to the soil and liberated through the mineralisation of the organic material is oxidised to nitrite $\left(\mathrm{NO}_{2}\right)$ and then to nitrate $\left(\mathrm{NO}_{3}\right)$. During this oxidation process, i.e. nitrification, $\mathrm{N}_{2} \mathrm{O}$ is also formed. The produced $\mathrm{NO}_{3}$ is then reduced to $\mathrm{N}_{2} \mathrm{O}$ or $\mathrm{N}_{2}$ under anaerobic conditions, i.e. denitrification, further contributing to $\mathrm{GHG}$ emissions. Application of wastewater sludge to soil can also increase emissions of $\mathrm{CH}_{4}$. Dissolved organic matter (DOM) in wastewaters can play a vital role on the degradation of endogenous and exogenous $\mathrm{OM}$ affecting $\mathrm{C}$ sequestration and $\mathrm{N}$ transformation in soils. The DOM can mediate mineralisation of organic carbon (C) into $\mathrm{CO}_{2}$ and $\mathrm{CH}_{4}$ as well as biological reduction of $\mathrm{NO}_{3}$ into $\mathrm{N}_{2}$ and $\mathrm{N}_{2} \mathrm{O}$. The aim of this chapter is to provide an overview on the GHG emissions from wastewater irrigated soils, and mitigation strategies to manage the GHG emissions.

\section{Wastewater sources}

Wastewater is derived from a number of sources that include municipal wastewater, farm wastewater, agricultural wastewater, stormwater. 


\subsection{Municipal wastewater}

Municipal wastewater is composed of domestic and industrial wastewater. Domestic wastewater consists of discharges from households, institutions, and commercial buildings. Figure 1 shows the potential volume of domestic sewage water generated in selected countries. Land application of this wastewater depends on the country or state legislations, the crop it is applied to, and the level of treatment. Municipal wastewater contains high concentrations of nutrients, especially $\mathrm{N}$ and phosphorus $(\mathrm{P})$, trace elements, such as iron $(\mathrm{Fe})$ and manganese $(\mathrm{Mn})$ and dissolved salts, particularly sodium $(\mathrm{Na})$, chloride $(\mathrm{Cl})$, and in some cases bicarbonates. Industrial effluents, mainly pulp and paper mill effluents are often irrigated to land after primary treatment. Pulp mill effluent has high chemical (COD) and biological oxygen demand (BOD), and some wood derived organic compounds, metal(loid)s, fatty and resin acids, and relatively high $\mathrm{C}: \mathrm{N}$ ratios.

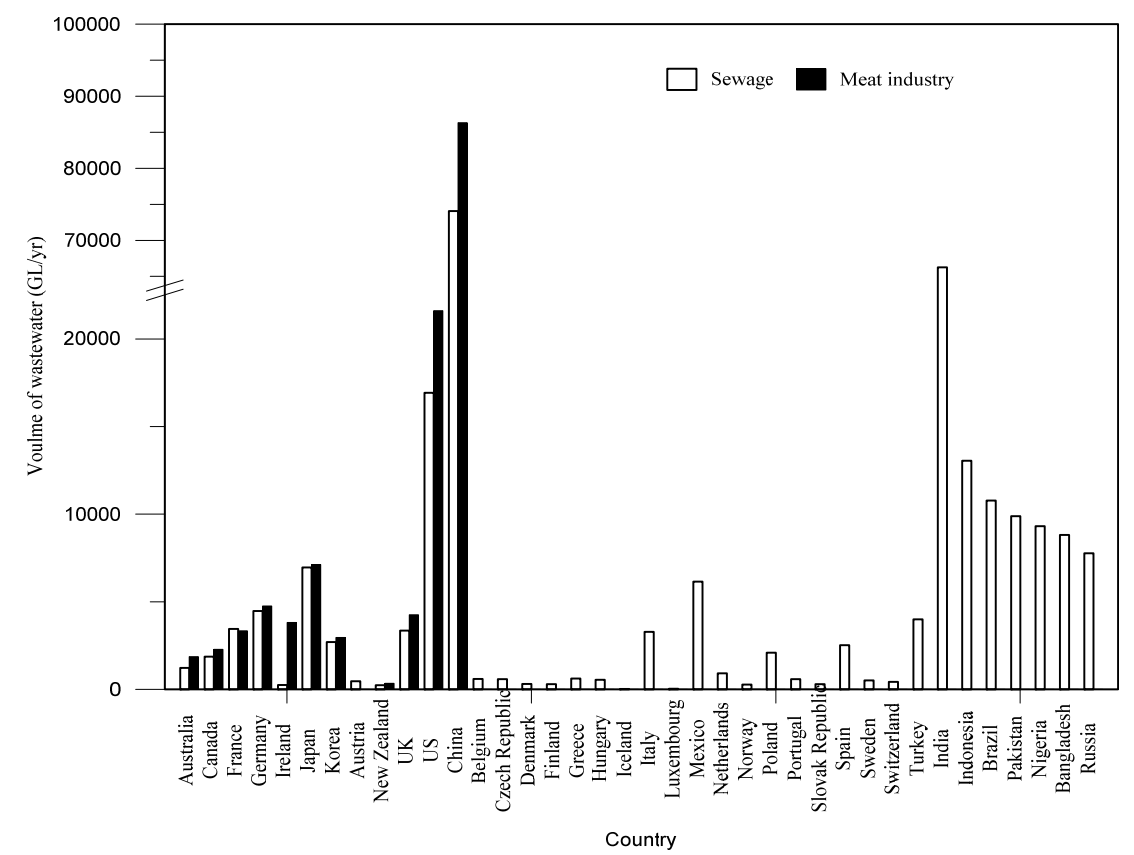

Figure 1: $\quad$ Potential quantities of sewage and meat industry wastewater (data not given for all countries) produced in selected countries (Water UK [3]).

\subsection{Farm wastewater}

Farm effluents from dairy sheds and piggeries are being increasingly employed as a source of irrigation water and nutrients in agriculture. For example, in New Zealand, dairy and piggery effluents generate annually about 9,000 $\mathrm{Mg}$ of $\mathrm{N}$, 
$1,250 \mathrm{Mg}$ of $\mathrm{P}$ and 14,000 $\mathrm{Mg}$ of potassium [4]. Effluents from farms differ in their composition depending on the animal production system from which they are derived (chicken, pigs, beef, and dairy). Generally, farm wastewater is rich in organic and inorganic components, and their application can increase crop yield due to the net loading of nutrients and water. In many regions, amount of farm effluents generated on a per farm basis exceeds the quantity that can be safely accommodated by the available agricultural land, and also repeated annual applications of large amounts of effluent can cause soil nutritional side effects and environmental damage.

\subsection{Effluents from the agricultural industry}

Recycling of agricultural industry effluents, notably effluents from animal treatment plants (fish processing plants, abattoirs) and vineyards are another common source of wastewater. For example, in Australia, agricultural drainage effluent is collected and reused as a source of irrigation water. Wastewater from intensive agricultural industries is characterised by high COD, BOD, and nutrients relative to many other wastewaters. Meat industries generate large volume of wastewater (Figure 1) and are usually disposed of to land due to high costs associated with independent treatment systems and environmental concerns over surface water discharge. Reuse of winery wastewater by grape growers and pastoralists is driven primarily through the obligations of the winery to dispose of their wastewater, preferably in a sustainable and cost-effective manner.

\subsection{Stormwater}

Urban stormwater harvesting has emerged in recent years as a viable option to reduce pressures on existing water sources and to alleviate adverse environmental impacts associated with stormwater run-off. This is a relatively abundant, local source of water, available throughout most urban areas. In Australia, for instance, approximately 10,300 million litres of stormwater are generated annually [5]. In many cases urban stormwater runoff contains a broad range of pollutants (pesticides, herbicides, oil, grease, and heavy metal(loids)) that are transported to natural water systems. Nutrients such as $\mathrm{N}$ and $\mathrm{P}$ are also important pollutants in stormwater. The harvesting of stormwater from industrial zones prior to its entry into natural waterways is likely to reduce the subsequent impact of point source discharge on surface waters by reducing pollutant loads.

\section{Greenhouse gas emission processes}

Wastewater application can lead to GHG emission by processes such as priming effect, methanogenesis, denitrification, and nitrification

\subsection{Prime effect}

Priming effect $(\mathrm{PE})$ is the stimulation of soil organic matter decomposition by the addition of wastewater which can lead to $\mathrm{CO}_{2}, \mathrm{CH}_{4}$, and $\mathrm{N}_{2} \mathrm{O}$ emissions. The 
prime effect can be caused by the change in microbial activity. The addition of the easily available organic $\mathrm{C}$ triggers the activity of soil microorganisms, usually at the rate much lower than the microbial biomass [6]. When the added substrate $\mathrm{C}$ is low, a linear increase of extra $\mathrm{CO}_{2}$ occurs with increasing amounts of added substrate $\mathrm{C}$, resulting in a positive $\mathrm{PE}$. When the amount of added substrate $\mathrm{C}$ is moderate, an exponential decrease in primed $\mathrm{CO}_{2}-\mathrm{C}$ is observed. When the amount of added substrate $\mathrm{C}$ is more than $200 \%$ of microbial $\mathrm{C}, \mathrm{PE}$ tends to be zero or negative [6]. Addition of wastewater to the soil either accelerates (positive $\mathrm{PE}$ ) or reduces $\mathrm{N}$ mineralisation or immobilises added $\mathrm{N}$ (negative PE). Priming effect increases soil mineral $\mathrm{N}$ shortly after $\mathrm{N}$ addition and this high soil mineral $\mathrm{N}$ content $\left(\mathrm{NH}_{4}{ }^{+}\right.$or $\left.\mathrm{NO}_{3}{ }^{-}\right)$can cause denitrification and hence $\mathrm{N}_{2} \mathrm{O}$ emission.

\subsection{Methanogenesis}

Methane production from soil is a strictly anaerobic microbial process known as methanogenesis and it requires low redox potential $(\mathrm{Eh}<-200 \mathrm{mV})$. Methane produced in the anaerobic zones can be oxidised to $\mathrm{CO}_{2}$ by another microbial process called methanotrophy. Methanotrophics, microorganisms involved in methanotrophy solely use $\mathrm{CH}_{4}$ as their substrate for growth. Hence, soil serves as a source of $\mathrm{CH}_{4}$ when the balance between $\mathrm{CH}_{4}$ production by methanogenic bacteria and consumption by methanotrophic is positive; as a sink of $\mathrm{CH}_{4}$ when the balance is negative [7].

\subsection{Nitrification}

Nitrification is a microbial process in which reduced forms of nitrogen $\left(\mathrm{NH}_{4}\right)$ are oxidised to $\mathrm{NO}_{2}{ }^{-}$and subsequently to $\mathrm{NO}_{3}{ }^{-}$. Nitrification occurs in two steps:

1) Autotrophic ammonium oxidation in which ammonia is oxidised to hydroxylamine (eqn. 1) and then to $\mathrm{NO}_{2}^{-}$(eqn. 2) by ammonia oxidising bacteria (AOB)

$$
\begin{aligned}
& \mathrm{NH}_{3}+\mathrm{O}_{2}+2 \mathrm{H}^{+}+2 \mathrm{e}^{-} \rightarrow \mathrm{NH}_{2} \mathrm{OH}+\mathrm{H}_{2} \mathrm{O} \\
& \mathrm{NH}_{2} \mathrm{OH}+\mathrm{H}_{2} \mathrm{O} \rightarrow \mathrm{NO}_{2}^{-}+5 \mathrm{H}^{+}+4 \mathrm{e}^{-}
\end{aligned}
$$

2) Autotrophic nitrite oxidation in which $\mathrm{NO}_{2}^{-}$is oxidised to $\mathrm{NO}_{3}^{-}$(eqn. 3) by autotrophic nitrite oxidising bacteria

$$
\mathrm{NO}_{2}^{-}+\mathrm{H}_{2} \mathrm{O} \rightarrow \mathrm{NO}_{3}^{-}+2 \mathrm{H}^{+}+2 \mathrm{e}^{-}
$$

In nitrification, $\mathrm{N}_{2} \mathrm{O}$ is produced from 2 pathways: nitrifier denitrification (eqn. 4) and hydroxylamine oxidation (eqn. 5). In nitrifier denitrification, under anaerobic or low $\mathrm{O}_{2}$ conditions, some AOB possess nitrite reductase activity and can denitrify $\mathrm{NO}_{2}{ }^{-}$to nitric acid and subsequently to $\mathrm{N}_{2} \mathrm{O}$ or $\mathrm{N}_{2}$. Thus incomplete nitrification results in the release of $\mathrm{N}_{2} \mathrm{O}$.

$$
\begin{gathered}
\mathrm{NH}_{3} \rightarrow \mathrm{NH}_{2} \mathrm{OH} \rightarrow \mathrm{NO}_{2}^{-} \rightarrow \mathrm{NO} \rightarrow \mathrm{N}_{2} \mathrm{O} \rightarrow \mathrm{N}_{2} \\
\mathrm{NH}_{3} \rightarrow \mathrm{NH}_{2} \mathrm{OH} \rightarrow \mathrm{NO} \rightarrow \mathrm{N}_{2} \mathrm{O}
\end{gathered}
$$

In hydroxylamine oxidation, hydroxylamine produced from ammonia oxidation is subsequently oxidised first to nitric oxide and then reduced to $\mathrm{N}_{2} \mathrm{O}$. 


\subsection{Denitrification}

Denitrification, the last step in soil $\mathrm{N}$ cycle is the reduction of $\mathrm{NO}_{3}{ }^{-}$to gaseous $\mathrm{N}$ products ( $\mathrm{NO}, \mathrm{N}_{2} \mathrm{O}, \mathrm{N}_{2}$ ) as mentioned in the below equation (eqn. 6).

$$
\mathrm{NO}_{3} \rightarrow \mathrm{NO}_{2} \rightarrow \mathrm{NO} \rightarrow \mathrm{N}_{2} \mathrm{O} \rightarrow \mathrm{N}_{2}
$$

Denitrification is performed by a diverse group of microorganism, bacteria, archea, and fungi, and catalysed by a range of enzymes (nitrate reductase, nitrite reductase, nitric-oxide reductase, nitrous oxide reductase). Denitrifying bacteria exhibit several reduction pathways which mainly depend on the substrate and its availability, and environmental conditions, thus resulting in the release of various products such as $\mathrm{N}_{2}$, or $\mathrm{N}_{2} \mathrm{O}$ or mixture of $\mathrm{N}_{2}$ and $\mathrm{N}_{2} \mathrm{O}$.

\section{Greenhouse gas emissions}

Wastewater contribute to $\mathrm{GHG}$ emission directly through the release of $\mathrm{CO}_{2}$, $\mathrm{CH}_{4}$ and $\mathrm{N}_{2} \mathrm{O}$ from $\mathrm{C}$ and $\mathrm{N}$ compounds present in the wastewater, and indirectly through their effects on soil properties thereby inducing GHG emission from soil (e.g. priming effect).

\subsection{Carbon dioxide emission}

Globally, $\mathrm{CO}_{2}$ from fossil fuel consumption is the most significant GHG, but it represents a relatively small component of emissions from the waste sector. Carbon dioxide is emitted when organic wastes are degraded in the presence of $\mathrm{O}_{2}$. However, this is not considered to add to the enhanced GHG effect because organic $\mathrm{C}$ is part of the natural $\mathrm{C}$ cycle, in which photosynthesis converts $\mathrm{CO}_{2}$ to organic matter which is subsequently converted back to $\mathrm{CO}_{2}$ through respiration, biodigestion or combustion. The net emission of $\mathrm{CO}_{2}$ from soil is due to two primary processes: 1) the production of $\mathrm{CO}_{2}$ (mainly respiration by plant roots and microbes) and 2) gas transport through the soil which controls the movement of $\mathrm{CO}_{2}$ from the soil to the atmosphere and $\mathrm{O}_{2}$ from the atmosphere to the soil. Organic material added through treated wastewater will increase the emission of $\mathrm{CO}_{2}$ due to decomposition. Fernández-Luqueño et al. [8] observed that applying urban wastewater to soil significantly increased the mean $\mathrm{CO}_{2}$ emission rate 2.4 times $(1.74 \mu \mathrm{gC} / \mathrm{kg}$ soil $/ \mathrm{h})$ compared to the unamended soil $(0.74 \mu \mathrm{gC} / \mathrm{kg} \mathrm{soil} / \mathrm{h})$, and cultivating maize further increased it 3.2 times $(5.61 \mu \mathrm{gC} / \mathrm{kg}$ soil $/ \mathrm{h})$. In a similar study, Xue et al. [9] noticed that the cumulative $\mathrm{CO}_{2}$ emission was significantly influenced by treated wastewater application on a silt loam soil. Large increases in $\mathrm{CO}_{2}$ fluxes have been observed immediately following application of farm effluents to soils, being attributed to the decomposition of labile $\mathrm{C}$ sources [10]. Higher heterotrophic respiration rates in the presence of slurry derived $\mathrm{C}$ and $\mathrm{N}$ also contribute to the release of $\mathrm{CO}_{2}$ from the pig slurryapplied soil [10]. 


\subsection{Methane emission}

Methane is an end product of the biological reduction of $\mathrm{CO}_{2}$ or organic $\mathrm{C}$ under anaerobic conditions. Methane emissions from all surface-applied slurries and animal waste effluents are generally very high immediately after application indicating the release of entrained gas produced during the storage. Sherlock et al. [11] suggested that an initial burst of $\mathrm{CH}_{4}$ soon after pig slurry application $\left(60 \mathrm{~m}^{3} / \mathrm{ha}\right)$ was probably due to release of entrained gas produced in the slurry pit before application. The slurry wastewater addition appeared to restrict $\mathrm{O}_{2}$ diffusion into the soil due to surface curst formation, thereby producing an anaerobic surface soil layer, where $\mathrm{CH}_{4}$ could be generated. $\mathrm{CH}_{4}$ emission from soil and volatile fatty acids in slurry are strongly correlated. Zou et al. [12] observed that sewage irrigated paddy cultivated land significantly increased $\mathrm{CH}_{4}$ emission by $27 \%$ and $33 \%$ with and without chemical $\mathrm{N}$ addition, respectively, relative to unpolluted river water irrigation. $\mathrm{Net} \mathrm{CH}_{4}$ emissions from soils are determined by the difference between $\mathrm{CH}_{4}$ formation where $\mathrm{O}_{2}$ is absent, and $\mathrm{CH}_{4}$ consumption where $\mathrm{O}_{2}$ is available, and is greatly affected by the water management system (depth of flooding, draining activities). Jiang et al. [13] studied the effects of sheep urine and dung patches on $\mathrm{CH}_{4}$ emission and indicated that the cumulative $\mathrm{CH}_{4}$ emissions for dung patches, urine patches and control plots were $-0.076,-0.084$, and $-0.114 \mathrm{~g} / \mathrm{m}^{2}$, respectively, indicating net $\mathrm{CH}_{4}$ sinks during the measured period. The level of $\mathrm{CH}_{4}$ intake from urine and dung plots decreased by $25.7 \%$ and $33.3 \%$, respectively, compared with the control plot and the cumulative $\mathrm{CO}_{2}$ emissions increased by 0.9 and $15.9 \%$ from urine and dung plots, respectively. They observed that the sheep excrement decreased $\mathrm{CH}_{4}$ intake and increased $\mathrm{CO}_{2}$ emission. Tenuta et al. [14] suggested that grassland soils with seasonally high water tables can be significant sources of $\mathrm{CH}_{4}$, and the emission increased when hog slurry was applied to soils.

\subsection{Nitrous oxide emission}

Nitrous oxide is formed in soils during the microbiological processes of nitrification and denitrification and is highly dynamic varying with time after wastewater application and the type of application. Effluent applications may cause relatively high $\mathrm{N}_{2} \mathrm{O}$ emissions when the soil contains $\mathrm{NO}_{3}$ and decomposition of organic $\mathrm{C}$ in farm wastewater enhances $\mathrm{N}_{2} \mathrm{O}$ emissions through both denitrification and nitrification processes [15]. In soils receiving repeated application of dairy farm effluent (DFE), frequent shifts between $\mathrm{N}_{2} \mathrm{O}$ and $\mathrm{N}_{2}$ production could be observed. Barton and Schipper [16] suggested that increased $\mathrm{N}_{2} \mathrm{O}$ emissions from DFE than inorganic $\mathrm{N}$ fertiliser was because of enhanced denitrification activity either by increasing $\mathrm{C}$ availability and/or decreasing soil aeration following increased respiration. Lowering the $\mathrm{C}$ content of animal slurry decreased the $\mathrm{N}_{2} \mathrm{O}$ emissions. Denitrification rates increased immediately after DFE irrigation, peaking at $24 \mathrm{~h}$, and then decreased to preirrigation rates after 3 days [16]. Other studies indicate similar trend with $\mathrm{N}_{2} \mathrm{O}$ emissions from three consecutive DFE irrigations, i.e. peaking within $24 \mathrm{hrs}$ of application [15] but it took 1-2 weeks for the emissions to reach the level of 
emissions from control treatment. These studies showed the emissions varied greatly depending on soil water filled pore space (WFPS) and the climatic conditions, and ranged from 2.04 to $5.69 \%$ of DFE-N applied. Increased soil moisture from irrigation and mineralisation of labile $\mathrm{C}$ and $\mathrm{N}$ from slurry applications favour nitrification and denitrification, resulting in highest $\mathrm{N}_{2} \mathrm{O}$ losses after fertilisation or manure slurry application [15].

Nitrous oxide emission is found to vary with the nature of effluent irrigation, application method, and season. For example, Khan [17] measured $1.9 \%$ and $0.1 \%-0.3 \%$ of the applied $\mathrm{N}$ as $\mathrm{N}_{2} \mathrm{O}$ emission from piggery effluent and DFE, respectively. The low $\mathrm{N}_{2} \mathrm{O}$ emissions from DFE may be attributed to the flooded irrigation of DFE. Saturated soil water conditions can reduce $\mathrm{N}_{2} \mathrm{O}$ emission by enhancing the complete reduction of $\mathrm{N}$ oxides to $\mathrm{N}_{2}$ gas. Higher denitrification losses were found following cattle slurry injection compared to surface application to a grassland soil [15]. Liquid-waste injections have been shown to promote conditions conducive to denitrification by creating an anaerobic environment abundant in inorganic $\mathrm{N}$ and readily oxidizable $\mathrm{C}$. Luo et al. [18] studied the effects of irrigating dairy-grazed grassland with FDE on $\mathrm{N}_{2} \mathrm{O}$ emissions and observed that FDE irrigation increased $\mathrm{N}_{2} \mathrm{O}$ emissions compared to the control and varied with changes in climatic conditions and soil WFPS. The $\mathrm{N}_{2} \mathrm{O}$ emissions increased slightly after application of FDE, reaching a peak value soon after application in both early autumn 2004 and late summer 2005. Then the $\mathrm{N}_{2} \mathrm{O}$ fluxes in the effluent treatment rapidly declined, and after 4-13 days were similar to those from the control.

\section{Factors affecting GHG emission}

GHG emission from wastewater applied soils is affected by a range of soil and environmental factors. The main factor in determining the extent of $\mathrm{CO}_{2}, \mathrm{CH}_{4}$ and $\mathrm{N}_{2} \mathrm{O}$ production is the amount of substrates including degradable organic matter (expressed as BOD or COD) and $\mathrm{N}$ in the effluent. The higher the $\mathrm{BOD} / \mathrm{COD}$ content the more $\mathrm{CH}_{4}$ and $\mathrm{CO}_{2}$ are produced. The potential amount of $\mathrm{CO}_{2}$ and $\mathrm{CH}_{4}$ production following farm wastewater application to fields will depend on manure type (solid, slurry, effluent), origin (type of animal), composition, time since application, as well as climatic and soil conditions. The factors that affect $\mathrm{CH}_{4}$ emission by soils are those that affect (1) Gas diffusion in relation with the oxydo-reduction level and $\mathrm{CH}_{4}$ transfer, in particular the water content, the nature of clays and the type of vegetation, (2) Microbial activities in general - temperature, $\mathrm{pH}$, Eh, substrate availability, physicochemical properties of soils etc, (3) Methanogenesis and in particular the competition with denitrification and sulphate-reduction and (4) Methane-mono-oxygenase activity - content in $\mathrm{H}_{2}, \mathrm{CH}_{4}, \mathrm{NH}_{4}^{+}, \mathrm{NO}_{3}^{-}$, Cu etc.

Soil characteristics such as organic $\mathrm{C}$ and $\mathrm{N}$ content, temperature, moisture, density and porosity, are directly related to gas exchange between soil and atmosphere. Factors such as WFPS, temperature/ season, and available $\mathrm{C}$ and $\mathrm{N}$ greatly influence $\mathrm{CO}_{2}$ flux from wastewater irrigated soils. For example, Rochette et al. [10] noticed that fluxes and cumulated $\mathrm{CO}_{2}-\mathrm{C}$ losses were greater 
for spring than for fall application. They hypothesized that larger amounts of $\mathrm{CO}_{2}$ would have solubilized in the soil solution in the fall because of higher water contents and lower temperature as compared with the spring. Urine addition to soils can result in increases in $\mathrm{CO}_{2}$ fluxes, over and above the amounts of $\mathrm{C}$ applied, with the release of native soil $\mathrm{C}$ indicative of a priming effect [19]. Xue et al. [9] measured $\mathrm{CO}_{2}$ emission from a silt loam soil irrigated with treated wastewater and noticed that the cumulative $\mathrm{CO}_{2}$ losses showed a maximum at $60 \%$ WFPS when $\mathrm{N}$ fertiliser was incorporated in soils. They also observed higher $\mathrm{CO}_{2}$ emissions in soils incubated at $60 \%$ and $80 \%$ WFPS compared to that in the drier (40\% WFPS) and wetter (100\% WFPS) soils. Sistani et al. [20] applied swine slurry to soil using various methods and observed that the method of application did not influence the $\mathrm{CO}_{2}$ emission. This indicated that the level of tillage used to incorporate the effluent through injection or aeration did not significantly increase $\mathrm{CO}_{2}$ emissions from no-till soils. Also they noticed that there were no significant differences in $\mathrm{CO}_{2}$ losses, which averaged 738 and $718 \mathrm{gCO}_{2} / \mathrm{m}^{2}$ in 2007 and 2008, respectively.

Nitrification and denitrification are controlled by environmental factors, cropping systems, soil management practices, inorganic or organic fertilisation, and by water regime. Temporal variations in $\mathrm{N}_{2} \mathrm{O}$ emission can also be explained by corresponding variations in soil temperature and water content. Water-filled pore space and soil $\mathrm{NO}_{3}$ concentrations are key factors affecting $\mathrm{N}_{2} \mathrm{O}$ emissions. Wastewater irrigation increases WFPS and a WFPS above $60 \%$ increases $\mathrm{N}_{2} \mathrm{O}$ losses due to denitrification [21]. Effluent applications enhance microbial activity, which reduces soil $\mathrm{O}_{2}$ levels, creating conditions that favour $\mathrm{N}_{2} \mathrm{O}$ emissions [15]. Carbon and $\mathrm{N}$ present in wastewater strongly influence $\mathrm{N}_{2} \mathrm{O}$ emission. Amon et al. [22] reported a $25 \%$ reduction in $\mathrm{N}_{2} \mathrm{O}$ emissions following the addition of anaerobically digested manure slurries compared with undigested liquid manure due to lower concentrations of labile $\mathrm{C}$ and $\mathrm{N}$ in the digested effluents. Zou et al. [12] noticed that relative to river water irrigation, sewage irrigation increased $\mathrm{N}_{2} \mathrm{O}$ by $68 \%$ and $170 \%$ from paddy fields with and without $\mathrm{N}$ application, respectively. In contrast to the above mentioned studies which highlight the importance of denitrification process in $\mathrm{N}_{2} \mathrm{O}$ emission, Master et al. [23] reported that reclaimed effluent application did not increase the $\mathrm{N} 2 \mathrm{O}$ emission. They suggested that the effluent treatment level (BOD5=100 mg/L) may have been low enough not to affect the $\mathrm{N}_{2} \mathrm{O}$ emissions in the short term

\section{Mitigation strategies}

Several management practices and technologies help mitigate GHG emissions from wastewater treated soils and, wastewater treatment and storage units. Reduced tillage could increase soil organic matter, enhance soil water-holding capacity and reduce the need for irrigation water. Increased soil organic matter could also improve natural soil fertility, thereby decreasing the need for inorganic fertilisers and organic amendments. Options to reduce the amount of excreta $\mathrm{N}$ produced, whilst maintaining total productivity, such as low $\mathrm{N}$ diets 
for dairy and intensive beef cattle, could yield a $15 \%$ reduction in $\mathrm{N}_{2} \mathrm{O}$ emissions. Options that increase the $\mathrm{N}$ use efficiency of excreta or fertiliser, such as the strategic use of stand-off pads or nitrification inhibitors, could reduce $\mathrm{N}_{2} \mathrm{O}$ emissions by up to $20 \%$. Improving the drainage of poorly or imperfectly draining soils, or avoiding soil compaction on these soils, is estimated to reduce $\mathrm{N}_{2} \mathrm{O}$ emissions by $7-10 \%$. In terms of the advanced fertilisation techniques, the use of nitrification inhibitors and/or slow release fertilisers has been shown to reduce $\mathrm{N}_{2} \mathrm{O}$ emissions substantially. Non-leguminous cover crops are efficient scavengers of residual soil $\mathrm{NO}_{3}$, thereby reducing leaching losses. Jarecki et al. [24] investigated the cover crop effects on $\mathrm{N}_{2} \mathrm{O}$ emission from a liquid swine manure-treated Mollisol. They observed a significant reduction in $\mathrm{N}_{2} \mathrm{O}$ emissions in the presence of rye. Luo et al. [18] suggested that strategic application of FDE during dry summer and autumn seasons could reduce $\mathrm{N}_{2} \mathrm{O}$ emissions and delaying effluent irrigation after grazing events could further reduce $\mathrm{N}_{2} \mathrm{O}$ emissions by reducing the levels of surplus mineral-N. Drainage system influence $\mathrm{CH}_{4}$ emission as well as $\mathrm{N}_{2} \mathrm{O}$ emission from waste water irrigated rice field. Multiple drainage and mid-season drainage at flowering period can help mitigate $\mathrm{CH}_{4}$ emission. Mid-season drainage reduced $\mathrm{CH}_{4}$ emissions by $43 \%$ because the flux of $\mathrm{O}_{2}$ into the soil created aerobic conditions, unfavourable to methanogenic bacterial activity [25]. It should be noted that in the aerobic zones of wetland and upland soils, $\mathrm{CH}_{4}$ is oxidised into $\mathrm{CO}_{2}$ by methanotrophs [15].

\section{Summary and conclusions}

Growing population, increased urbanisation, improved living conditions and economic development have led to a considerable increase in the volume of wastewater generated by domestic, industrial and commercial practices. The use of treated wastewater for both agricultural production and environmental protection has increased in recent years in several continents including Australia, Europe and North America. Adequate management of wastewater irrigated soils and crops results in a reduction of GHG emissions by storing atmospheric $\mathrm{C}$ as soil organic matter. Though major sources and factors controlling trace gas emissions from wastewaters and waste management systems are well known, further research and development is needed to improve the accuracy and utility of these tools.

\section{Acknowledgement}

The Postdoctoral fellowship program (PJ00865042012) at National Academy of Agricultural Science, Rural Development Administration, Republic of Korea, supported Dr. Kunhikrishnan's contribution. 


\section{References}

[1] Climate change 2007: The physical science basis; Intergovernmental Panel on Climate Change Change (IPCC), Summary of policy Makers, http://www.ipcc.ch/SPMfeb07.pdf.

[2] Mackenzie, F.T. and Mackenzie, J.A., Our changing planet: An introduction to earth system science and global environmental change, Prentice Hall: NJ, pp. 486, 1998.

[3] Water UK., Wastewater treatment and recycling, 2006,http://www.water.org.uk/home/news/press-releases/wastewaterpamphlet/wastewater-web--2-.pdf

[4] Bolan, N. S., Adriano, D. C. and Wong, C., Nutrient removal from farm effluents. Bioresource Technology, 94(3), pp. 251-260, 2004.

[5] Laurenson, S., Kunhikrishnan, A., Bolan, N., Naidu, R., McKay, J. and Keremane, G., Management of recycled water for sustainable production and environmental protection: A case study with Northern Adelaide Plains recycling scheme. International Journal of Environmental Science and Development, 1(2), pp. 176-180, 2010.

[6] Blagodatskaya, E. and Kuzyakov, Y., Mechanisms of real and apparent priming effects and their dependence on soil microbial biomass and community structure: critical review. Biology and Fertility of Soils, 45(2), pp. 115-131, 2008.

[7] Dubey, S., Microbial ecology of methane emission in rice agroecosystem: a review. Applied Ecology and Environmental Research, 3(2), pp. 1-27, 2005.

[8] Fernández-Luqueño, F., Reyes-Varela, V., Cervantes-Santiago, F., GómezJuárez, C., Santillán-Arias, A. and Dendooven, L., Emissions of carbon dioxide, methane and nitrous oxide from soil receiving urban wastewater for maize (Zea mays L.) cultivation. Plant and Soil, 331(1), pp. 203-215, 2010.

[9] Xue, Y., Yang, P., Luo, Y., Li, Y., Ren, S., Su, Y. and Niu, Y., Characteristics and Driven Factors of Nitrous Oxide and Carbon Dioxide Emissions in Soil Irrigated with Treated Wastewater. Journal of Integrative Agriculture, 11(8), pp. 1354-1364, 2012.

[10] Rochette, P., Angers, D.A., Chantigny, M.H., Bertrand, N. and Côté, D, Carbon dioxide and nitrous oxide emissions following fall and spring applications of pig slurry to an agricultural soil. Soil Science Society of America Journal, 68(4), pp. 1410-1420, 2004.

[11] Sherlock, R.R., Sommer, S.G., Khan, R.Z., Wood, C., Guertal, E.A., Freney, J.R., Dawson, C.O. and Cameron, K.C., Ammonia, methane, and nitrous oxide emission from pig slurry applied to a pasture in New Zealand. Journal of Environmental Quality,31(5), pp. 1491-1501, 2002.

[12] Zou, J., Liu, S., Qin, Y., Pan, G. and Zhu, D., Sewage irrigation increased $\mathrm{CH}_{4}$ and $\mathrm{N}_{2} \mathrm{O}$ emissions from rice paddies in southeast China. Agriculture, Ecosystems \& Environment, 129(4), pp. 516-522, 2009. 
[13] Jiang, Y., Tang, S., Wang, C., Zhou, P. and Tenuta, M., Contribution of urine and dung patches from grazing sheep to methane and carbon dioxide fluxes in an Inner Mongolian desert grassland. Asian-Australian Journal of Animal Sciences, 25, pp. 207-212, 2012.

[14] Tenuta, M., Mkhabela, M., Tremorin, D., Coppi, L., Phipps, G., Flaten, D. and Ominski, K., Nitrous oxide and methane emission from a coarsetextured grassland soil receiving hog slurry. Agriculture, Ecosystems \& Environment, 138(1), pp. 35-43, 2010.

[15] Saggar, S., Bolan, N.S., Bhandral, R., Hedley, C. and Luo, J., A review of emissions of methane, ammonia, and nitrous oxide from animal excreta deposition and farm effluent application in grazed pastures. New Zealand Journal of Agricultural Research, 47(4), pp. 513-544, 2004.

[16] Barton, L. and Schipper, L., Regulation of nitrous oxide emissions from soils irrigated with dairy farm effluent. Journal of Environmental Quality, 30(6), pp. 1881-1887, 2001.

[17] Khan, R.Z., Influence of soil water potential, soil temperature and soil gas composition on the generation, absorption and transportation of soil gases. Unpublished PhD Thesis, Lincoln University, New Zealand,1999.

[18] Luo, J., Saggar, S., Bhandral, R., Bolan, N., Ledgard, S., Lindsey, S. and Sun, W. 2008., Effects of irrigating dairy-grazed grassland with farm dairy effluent on nitrous oxide emissions. Plant and Soil, 309(1), pp. 119-130, 2008.

[19] Clough, T., Sherlock, R. and Kelliher, F., Can liming mitigate $\mathrm{N}_{2} \mathrm{O}$ fluxes from a urine-amended soil? Soil Research, 41(3), pp. 439-457, 2003.

[20] Sistani, K., Warren, J., Lovanh, N., Higgins, S. and Shearer, S., Greenhouse gas emissions from swine effluent applied to soil by different methods. Soil Science Society of America Journal, 74(2), pp. 429-435, 2010.

[21] Bateman, E. and Baggs, E., Contributions of nitrification and denitrification to $\mathrm{N}_{2} \mathrm{O}$ emissions from soils at different water-filled pore space. Biology and Fertility of Soils, 41(6), pp. 379-388, 2005.

[22] Amon, B., Kryvoruchko, V., Amon, T. and Zechmeister-Boltenstern, S., Methane, nitrous oxide and ammonia emissions during storage and after application of dairy cattle slurry and influence of slurry treatment. Agriculture, Ecosystems \& Environment, 112(2), pp. 153-162, 2006.

[23] Master, Y., Laughlin, R., Shavit, U., Stevens, R. and Shaviv, A., Gaseous nitrogen emissions and mineral nitrogen transformations as affected by reclaimed effluent application. Journal of Environmental Quality, 32(4), pp. 1204-1211, 2003.

[24] Jarecki, M.K., Parkin, T.B., Chan, A.S.K., Kaspar, T.C., Moorman, T.B., Singer, J.W., Kerr, B.J., Hatfield, J.L. and Jones, R., Cover crop effects on nitrous oxide emission from a manure-treated Mollisol. Agriculture, Ecosystems \& Environment, 134(1), pp. 29-35, 2009.

[25] Corton, T., Bajita, J., Grospe, F., Pamplona, R., Asis, C., Wassmann, R., Lantin, R. and Buendia, L., Methane emission from irrigated and intensively managed rice fields in Central Luzon (Philippines). Methane Emissions from Major Rice Ecosystems in Asia, pp. 37-53, 2001. 